\title{
FARMERS EMPOWERMENT THROUGH SOCIAL ENGINEERING AND RENTING OUT EQUIPMENT
}

\author{
Biradar Aishwarya \\ Department of Computer Engineering, \\ Marathwada Mitra Mandal's Polytechnic, \\ Pune-411033, Maharashtra, India. \\ Vaidya Neha \\ Department of Computer Engineering, \\ Marathwada Mitra Mandal's Polytechnic, \\ Pune-411033, Maharashtra, India.
}

\begin{abstract}
The Farmer's Empowerment Project aim that helping the poorest farmers and workers through Social Engineering. The effective management of unorganized manpower in the sector of agriculture will be done by an application, farmers and daily wage workers working in villages, mainly in agriculture sector, can register on this app. A farmer in needed of additional manpower can post an hour basis requirement on the application daily wages workers can respond to such requirement and both get a platform to fulfill their requirements. Small scale farmers would be benefitted most by this application and save their efforts of looking for labors. Even farmers can earn money by responding to such labor requirements on the application. It is not only for single village but also for different villages.
\end{abstract}

Keywords-Empowerment, bartar.

\section{INTRODUCTION}

Agriculture is the backbone of the Indian economy and will remain so for the next century or so. About $65 \%$ of the Indian population depends on agriculture for their livelihood. The current situation of farmers is precarious due to many factors like changing weather, unavailability of water, low quality of seeds and pesticides, cost of crop and unavailability of human resources in agricultural sector. Nowadays labours are not available easily since it is unorganized, many farmers don't get labours when needed whereas many labours don't get daily work assignments. SO, in this application we are utilizing manpower.

\author{
Jagdale Priti \\ Department of Computer Engineering, \\ Marathwada Mitra Mandal's Polytechnic, \\ Pune-411033, Maharashtra, India, \\ Solanke Vikas \\ Head Of Department, Computer Engineering \\ Marathwada Mitra Mandal's Polytechnic, \\ Pune-411033, Maharashtra, India.
}

\section{TECHNOLOGY USED}

At front end we have used 'HTML' and 'CSS', JAVA' ,'JSP' at the backend we have used database for database we used MySQL.

\section{SOFTWARE REQUIREMENT}

1) Ecllipse JEE.

2) MYSQL Installer 8.0.

3) Apache Tomcat Server 9.0.

\section{MODULE}

1) Registration: As soon as the user joins, the admin provides unique username and password to him.

2) Farmer: When a new farmer registers, his record is saved in the database.

3) Payment Methods: Here payment is calculated for each worker based on the type of payment i.e. commercial or bartar. Farmer need not pay for entire day he can work instead of payment or he can pay also. Same thing appear in instrument and animal.

4) Display: A user can view the record of skills required for farming and workdone. And user can also view record of animals and instruments.

5) Report: Here reports of entry of work, animal entry, instrument entry generates automatically 
International Journal of Engineering Applied Sciences and Technology, 2020

Vol. 4, Issue 11, ISSN No. 2455-2143, Pages 424-428

Published Online March 2020 in IJEAST (http://www.ijeast.com)

V. DATAFLOW DIAGRAM

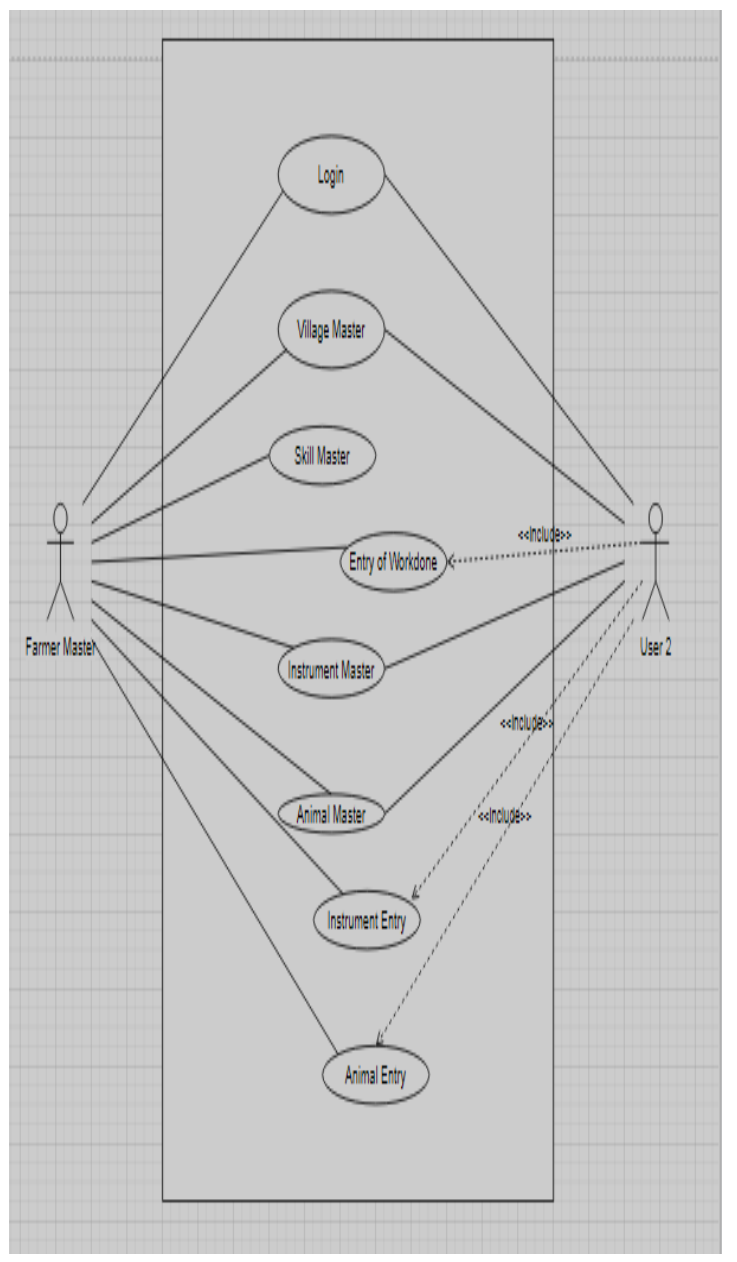

VI. SYSTEM INTERFACES

1) Login Page

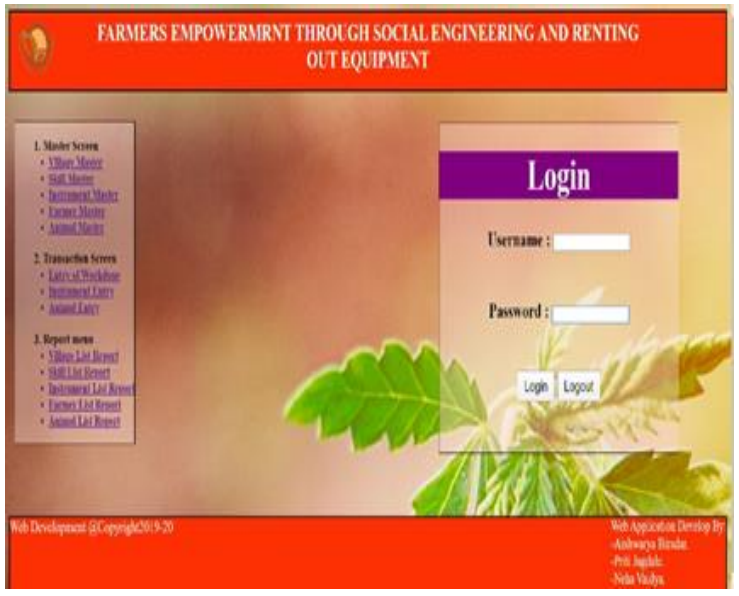

2) Village Master

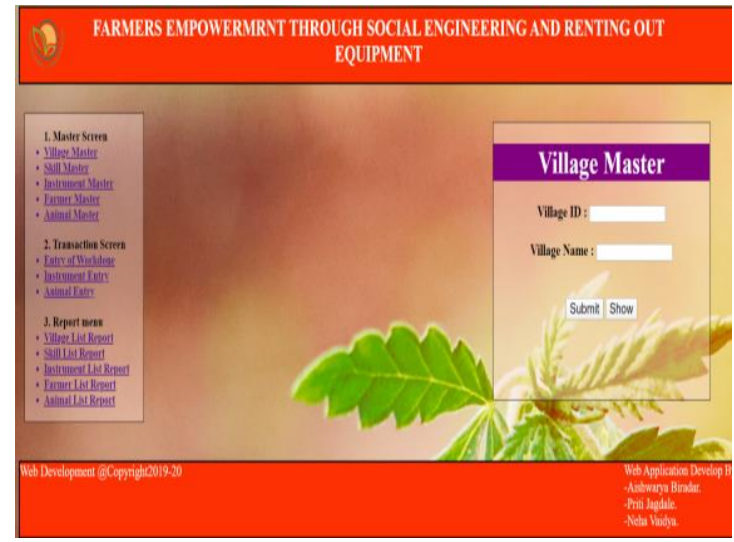

3) Skill Master

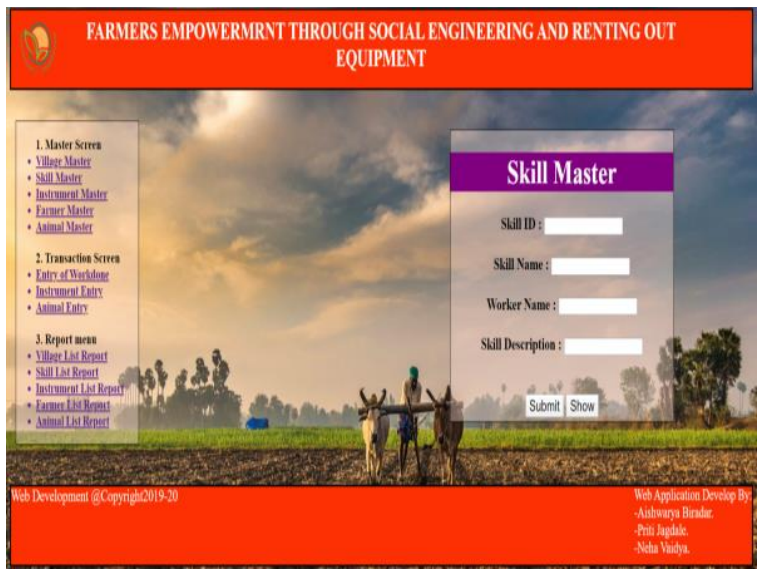

4) Farmer Master

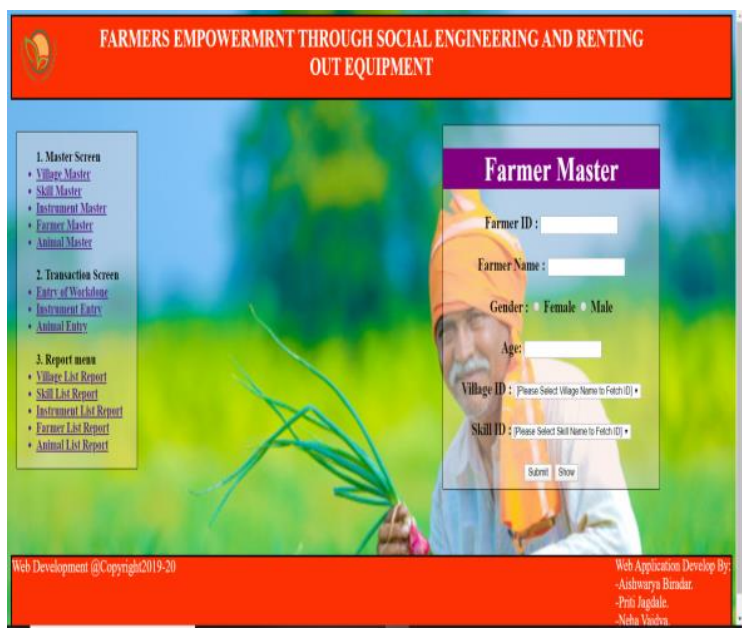


International Journal of Engineering Applied Sciences and Technology, 2020

Vol. 4, Issue 11, ISSN No. 2455-2143, Pages 424-428

Published Online March 2020 in IJEAST (http://www.ijeast.com)

5) Instrument Master

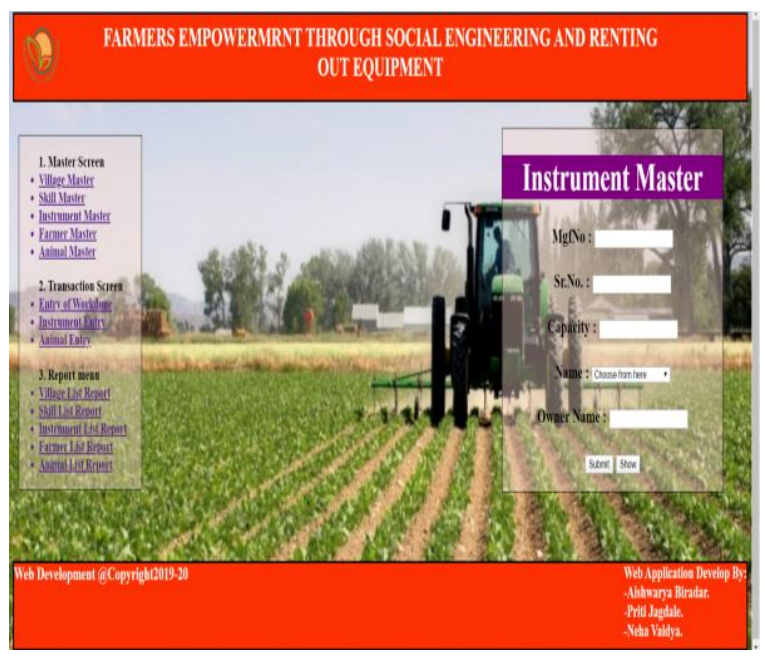

6) Animal Master

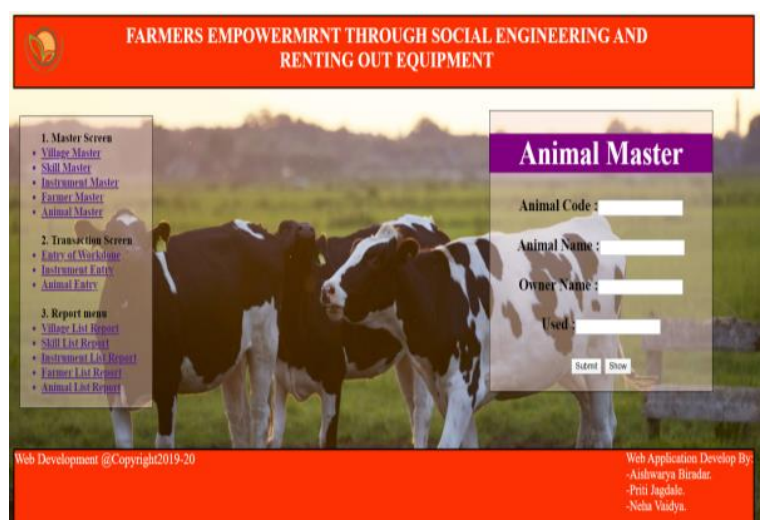

7) Entry Of Workdone

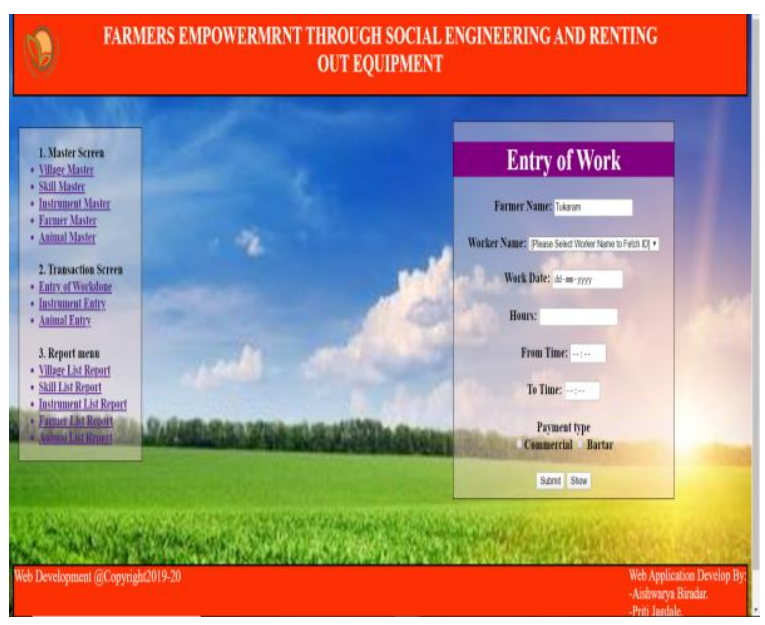

8) Animals Entry

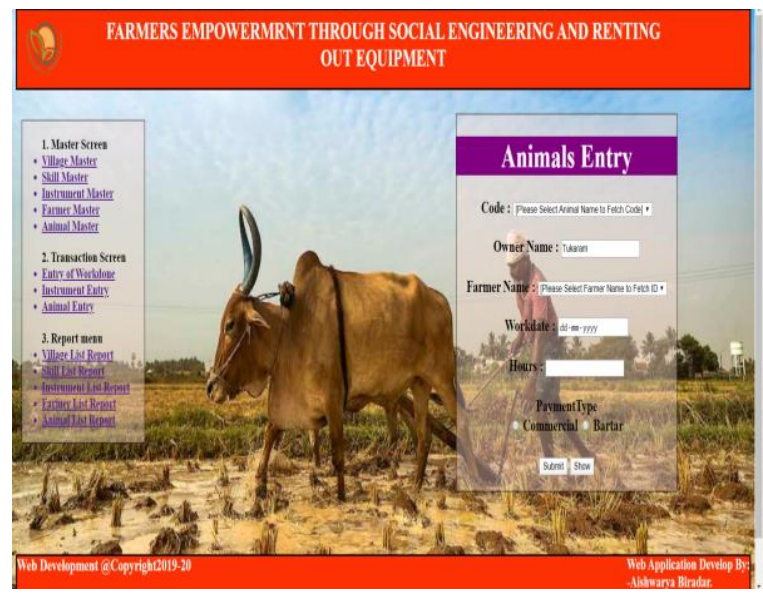

9) Instrument Entry

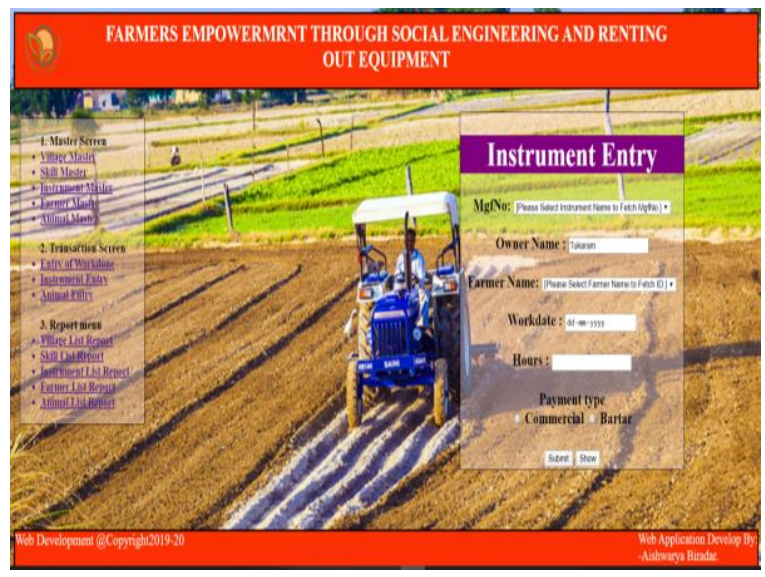

\section{APPLICATIONS}

1) This application can be used for big and small scale farmers.

2) This application not only for single village but also for different villages.

\section{ADVANTAGES}

1) Solving problems of poor farmers and labors.

2) Reduce the agricultural unemployment

3) Available for a any number of farmers.

4) The effective management of unorganized manpower in the sector of agriculture.

5) Scope for updation and development in application for future. 


\section{International Journal of Engineering Applied Sciences and Technology, 2020 \\ Vol. 4, Issue 11, ISSN No. 2455-2143, Pages 424-428 \\ Published Online March 2020 in IJEAST (http://www.ijeast.com)}

\section{SCOPE}

1) This Application can be used in Agricultural Industries.

2) It can be develop and upgrade in future.

3) Small scale farmers can get benefit by this application.

4) It can develop in Android Application which is easy to use for farmers.

\section{CONCLUSION}

The software keeps record of farmer's skills, daily assignments, entry of work, animal entry and instrument entry. The software is capable of easy storage of information related to farmer through database. Reports of work done generates automatically in this application. Worker get his daily work easily through this application. The bond between farmers will strong by doing work and by sharing instruments and animals.

\section{ACKNOWLEDGEMENT}

Perseverance, Inspiration \&amp; Motivation have always played a key role in the success of any venture. At this level of understanding it is difficult to understand the wide spectrum of knowledge without proper guidance and advice, Hence we take this o to express our sincere gratitude to our respected Project Guide Mr.V.S.Solanke who as a guide evolved an interest in us to work and select an entirely new idea for project work. He have been keenly co-operative and helpful to us in sorting out all the difficulties.

We would also like to thank our Principal MRS. GEETA JOSHI, for their continuous advice and support.

I would also thank My Institution and my faculty members without whom this project would have been a distant reality.

\section{REFERENCE}

1. Velychko, O. and L. Velychko, 2017. Management of inter-farm use of agricultural machinery based of the logistical system "BOA". Bulg. J. Agric. Sci., 23 (4): 534-543.

2. Shin et al. Web-based Agricultural Machinery Rental Business Management System Journal of Biosystems Engineering, Vol. 39, No. 4, 2014.

3. Parminder Kamboj, Rohinish Khurana, Anoop Dixit (Department of Farm Machinery and Power Engineering Punjab Agricultural University, Ludhiana, India), December,2012.

4. 2018 by Sunil Goria, Sanjay K. Bihani and K. L. Mahawar.This work is made available under the terms of the Creative Commons Attribution 4.0 International License.

5. Nia Desiana and Atik Aprianingsih ,The sian Journal of Technology Management Vol. 10 No. 1 (2017): 41-47.

6. Draft paper for ECOSOC Expert Group Meeting on Promoting Empowerment of People in Advancing Poverty Eradication, Social Integration, and Decent Work for All, UN HQ, NYC, September 10-12, 2012.

7. 2nd Asia Pacific Conference on "Managing Business Sustainability", At Jaipuria Institute of Management, Lucknow during 15-17 December 2017

8. The Asian Journal of Technology Management Vol. 10 No. 1 (2017): 41-47

9. Scientifical Journal Ranking(SJR): .259 National Academy of Agricultural Sciences (NAAS): 4.86 Online ISSN: 0976-058X Month(s) of publication: February, April, June, August, October and December

10. Limbore Nilesh V. and Khillare Shrirang K. ,"AN ANALYTICAL STUDY OF INDIAN AGRICULTURE CROP PRODUCTION AND EXPORT WITH REFERENCE TO WHEAT" Review of Research | Volume 4 | Issue 6 | March 2015

11. Adio, Emmanuel Olorunnishola; Abu, Yusufu; YUsuf, Sheriff Kunle; and Nansoh, Shehu, "Use of Agricultural Information Sources and Services by Farmers for Improve Productivity in Kwara State" (2016). Library Philosophy and Practice (e-journal). 1456.

12. Journal of Agricultural Extension Abstracted by: EBSCOhost, Electronic Journals Service (EJS), Vol. 22 (1) February, 2018

13. International Journal of Social Relevance \& Concern ISSN-2347-9698 Volume 4 Issue 2 February 2016.

14. 1st Unnes International Conference on Research Innovation \& Commercialization for the Better Life 2015, At Semarang, Indonesia, Volume: ISSN: 24605832

15. International Journal of Advanced Educational Research ISSN: 2455-6157; Impact Factor: RJIF 5.12 
International Journal of Engineering Applied Sciences and Technology, 2020

Vol. 4, Issue 11, ISSN No. 2455-2143, Pages 424-428

Published Online March 2020 in IJEAST (http://www.ijeast.com)

www.educationjournal.org Volume 1; Issue 3; May 2016

16. Dr. Kulamani Padhi is the Asst. Registrar, Dairy Coop. Societies, Directorate of A.H. and V.S., Orissa, Cuttack.

17. International Journal of Social Science \& Interdisciplinary Research Vol.1 Issue 9, September 2012, ISSN 22773630

18. A Study on the Current Trend of Agricultural Productivity in India and its Future Prospects. Volume 2, Issue 4, April 2015, PP 16-21 ISSN 23490373 (Print) \& ISSN 2349-0381 (Online)

19. AGRICULTURAL MECHANIZATION AND AUTOMATION - Vol. I - Human and Animal Powered Machinery - P.M.O. Owende 